\title{
Financial Habits of Savings by Customers of a Banking Entity
}

\author{
M.F. María Esther Mayagoitia Sánchez ${ }^{1}$, Dra. Laura Guillermina Duarte Cáceres ${ }^{2}$, Dra. \\ Yolanda Leonor Rosado Muñoz ${ }^{3 *}$ \\ ${ }^{1,2,3}$ Autonomous University of Yucatán, México
}

\begin{abstract}
*Corresponding Author: Dra. Yolanda Leonor Rosado Muñoz, professor and coordinator of the Master's Degree in Finance program at the Autonomous University of Yucatán, México
\end{abstract}

\begin{abstract}
The purpose of this study is identify the savings habits and instruments of the clients of a bank in the city of Mérida, Yucatán. This is a cualitative study; the method used in this research is descriptive work through a multiple case study with a non-experimental design and cross-sectional section. Convenience sampling with a selection of 15 clients who agreed to answer a structured interview. The results of this study indicate the people who save are between the ages of 30 and 40 and, in terms of gender, men are the most savers. It was found that a graduate degree is not a characteristic that differentiates a saved from a nonsaver. It was also found that even people with incomes over \$30,000 did not save, and people with incomes between \$10,0000 and \$15,000 do have the habit of saving. Conclusion: The financial habits of account holders who save are: managing a budget, controlling their income, debt, spending and saving, saving for contingencies and saving for retirement.
\end{abstract}

Keywords: Financial habit, Savings, Bank, Financial education.

\section{INTRODUCTION}

In particular, inflationary pressures, bank interest rates, the increase of exchange rate, mentioning among others factors, had impact directly in the mexican economy by increasing the prices of the products of the basic food basket and services, in the last few years (Ros, 2018). Likewise, the mexican economy it's been impacted by the discourse of the president of the United States of America, Donald Trump, towards Mexico, and the protectionist politic that postulate as the government guideline, which has generated uncertainty and pessimistic projections in the economic growth of Mexico.

This is reflected on a direct impact in the budget of people, the goods they could acquired with a certain amount of income are much lower today, which means a bigger expense to cover personal and family needs and also motivates the search for new alternatives to increase purchasing power (Zozaya, 2016).

It is of great importance that people has a wider knowledge in the way they distribute their income, as well as how to have a saving culture. Saving is fundamental en the countries development because establish the main source of resources for the financing of investment, as well as the generation of proyects of structural reform that promote economic and social development (Huidobro 1995).

In México, $60 \%$ of the population tend to save, of this percentage, $43.7 \%$ use informal methods of saving (Flores, 2013). By not using formal methods of saving, the development of a formal culture of saving gets discouraged (save set amounts in specific periods). The author also emphasizes that among the main causes for this behavior, two factors stand out: the first is misinformation, because, when the financial products available for savings are not known, they are not taken advantage of them. The second corresponds to the indices of the unbanked population, since the manipulation of money and the trend towards work and the informal economy accentuate this economic behavior.

By other hand, $38 \%$ of adults in the world, does not use formal financial services and a larger percentage of people with lower incomes, does not have a bank account due to the costs or the strict requirements from the bank institutions to opening an account. (Banco Mundial, 2015). 
Another interesting fact according to The Standard and Poor's rating agency cited by Forbes magazine (2016), is the fact that worldwide only $35 \%$ of adult men have knowledge of financial education, compared to $30 \%$ of women.

In Mexico, $51 \%$ of young people rather to save their money at home, $47 \%$ do it through bank accounts, six out of ten older adults do not receive a pension and $86 \%$ of older adults regret not saving for that stage of his life (National Commission for the Protection and Defense of Users of Financial Services, CONDUSEF, 2014).

Against the need to prepare for future financial contingencies and the great diversity of methods and motivations for saving, it becomes relevant to find mechanisms to segment people according to the habits with which they provide resources.

Based on what is stated in previous paragraphs, the research objective gets generated. Identify the savings habits and instruments for customers of a bank entity in the city of Mérida, Yucatán

\section{THEORETICAL FRAMEWORK}

\subsection{Financial Education}

Financial education gives power to the people allowing them to manage in a better way their resources and their family finances. (Latin American Development Bank, 2013). On the other hand, knowing about financial education also helps investors to keep track of intermediaries; if families have greater knowledge and notions about risk and return, interest and inflation, they can more easily identify abuse and fraud. Investors must be able to evaluate and purchase the services that financial institutions provide.

The benefits of financial education also extend to the economy in general since it promotes the skills necessary to make informed and appropriate decisions, as well as tools so that individuals have the ability to defend their rights as financial users (Latin American Development Bank, 2013).

Torres (2015) saids that in Mexico there is little knowledge towards profit of financial savings, investment, insurance and credit products, coupled with the problems of millions of individuals without access to this sector. In the country only $10 \%$ of financial institutions promote education programs on the products and services they offer. On the other hand, based on the 45 banks that operate in the country, only 5 promote education programs, according to information reported in the bureau of Financial Institutions

\subsection{Personal Finances}

There is diversity among the definitions, depending on the sources of information that are consulted. Lanzagorta (2015) explains that personal finances are a set of tools that support us to improve the quality of life and mainly to achieve the different goals and objectives. Also, Chu (2017) comments that it is the process of planning income, expenses, financing and investment to improve our financial situation.

Personal and family finances are divided into five categories: income, expenses, debts, savings and investment (Delgado, 2009), which are defined below:

\subsection{Financial Habits}

The word habit can be defined as "form of behavior acquired by the repetition of the same acts" (Gómez, 1997 s.p).

\subsection{Savings in Mexico}

Saving can be defined as that part of income that is not consumed or, to put it another way, is the total income that a person receives as a counterpart for a service provided, this income according to Dornbusch y Fischer (2012) can only be used in two ways: consuming it or saving it, which according to accounting forms can be identified as:

$$
\mathrm{S}=\mathrm{Y}-\mathrm{C} \text { where: } \mathrm{S}=\text { Saving } \mathrm{Y}=\text { Income } \mathrm{C}=\text { Consumption }
$$

Saving is a necessity that many people desire, since it can improve the life quality of those who practice it, in addition this also takes relevance as a central issue in the formulation of public politics and academic debates (Aguilar y Valles 2015). The Financial Network Credomátic (2008, p.182) recommends "saving between 5 to $15 \%$ of your income depending of course on your financial situation." 
As proof is that recently actions have been implemented for better education and financial inclusion, such as the inclusion in 2007 within the Credit Institutions Law that indicates that banking institutions offer basic bank accounts that facilitate access to banking services to low-income people.

In some studies (Aguilar y Valles 2015) Other efforts have been documented to understand the possible determinants of savings. Most of the studies consulted agree that income is a fundamental determinant for saving and under certain assumptions this behavior could be modifiable. Internationally demographic indicators and those related to income sources are used as explanatory variables.

Saving can be treated as formal or informal, since formal saving can be made in financial and banking institutions, on the other hand, informal saving is concentrated in personally assuming the safeguarding of capital or transferring it to a third party not legally certified to perform that task (Iregui-Bohorquez, et al., 2018).

Similarly, a series of barriers have been determined that discourage the use of formal savings instruments (Vazquez, 2015). According to the National Survey of Financial Inclusion, the main barriers to the use of formal financial instruments are the followings:

1. Lack of Resources to Save

2. Regulatory Barriers

3. Lack of Access

Vázquez (2015) indicates that other factors that affect the use of formal savings instruments are location, education, monthly income level and age.

\subsection{Savings Determinants}

Within the great variety of social and economic relationships where economic agents arise, there are countless reasons why individuals make the decision to save, these reasons are generally concentrated in two main slopes: the reasons and the determinants of saving. According to Villagómez (1993), The reasons for saving refer to the circumstances according to which it is decided not to consume the entire income of the individual, that is, the destination that will be given in the future to the unspent income, while the determinant of saving is about the variables economic and non-economic that individuals consider to determine their level of savings. In the same way, he comments that the reasons why an individual saves are fundamentally four: 1) the forecast of consumption expenses that will be incurred after retirement from economic activity, which depend on the stage of life in which it is found and which acts in a long-term horizon; 2) caution against uncertainties that might arise in the short term; 3) the planning that is done to invest or to place funds at a positive real interest rate and 4) the need or desire to leave a legacy or inheritance.

The most important determinants of the savings level of the economies are generally: the level of income, liquidity restrictions, the interest rate, inflation, the exchange rate, foreign savings, and income distribution (Villagomez 1993).

\subsection{Savings Tools}

This section is dedicated to describe some of the savings instruments most widely used in Mexico. It generates a context for the information collection instrument that is applied in the subsequent.

\section{Savings Account}

A savings account is a financial product offered by banks that allows you to deposit amounts to save and obtain a return on them. It is said that these accounts are a financial product "at sight", because the funds are immediately available: you can deposit or withdraw money from the account whenever you want (Condusef, 2014). Although these accounts may be subject to commission payments, the increasingly popular trend is that savings products are not charged by commissions.

\section{Savings Banks or Popular Savings Banks}

The formal name of these institutions is Cooperative Savings and Loan Societies (SOCAP). This, according to the website of the National Commission of Banking and Value (CNBV, 2018). By definition

"They are those companies constituted and organized with the purpose is to carry out savings and loan operations with their partners, and who are part of the Mexican Financial System 
with the character of members of the popular sector, without speculative intention and recognizing that they are not financial intermediaries with the purpose of profit".

\section{Mutualist}

Condusef (2014) explains that "mutuality" is known as "associations of people who, without giving policies or contracts, grant their members coverage in the event of death, benefits in accidents and illnesses or compensation for damages. (mainly automovilistic), among others." Similarly, these associations are also regulated by the National Insurance and Bond Commission, which also supervises them.

You also hear the term "tanda" which is used as a form of savings especially in people with low salaries. This type of saving is very easy to carry out, however, it is very risky, since there is no contract or guarantee of return of savings and it is considered as an informal method of saving.

The financial page Coru (2019) describes a "tanda" as:

"A group of people organize to save money. The group objective is to save a certain amount and everyone will make a contribution every certain time, the amount saved is the result of everyone's contribution. For everyone to receive their part, they will be assigned with turn and then receive the money on a certain date. Within this group there is a coordinator who defines the order in which each participant will receive the income."

\section{Safe Deposit Boxes}

The BBVA page (2015) describes safe deposit boxes as a service offered privately where, in addition to storing cash, other possession can also be kept, such as jewelery and documentation, what is kept in them is totally confidential.

\section{Method}

This research it is a descriptive type with a qualitative approach. It is a non-experimental study because the variables are not manipulated and the study subjects are analyzed in their natural context for subsequent analysis.

It has a cross-section since the information analyzed through a structured interview with clients of a bank was collected at a specific time, this being the month of October 2019. It was selected a multiple case study method. According to Blaxter, Hughes and Tight (2000), the multiple case study is compatible with the needs of researchers on small-scale, since it allows an approach to the cases that can be the same place of work of the researcher, or any other organization that has easy access to the information that allows to carry out the investigation in a satisfactory way.

\subsection{Population and Sample}

By customer of a bank branch refers to any person who requests a product or service from the bank.

Given the characteristics of the population and the customer service mechanism, it is proposed to carry out structured interviews to a sample with the following characteristics: Economically active men and women.

- Age range from 30 to 60 años.

- With an income of $\$ 10,000$ to $\$ 50,000$ monthly pesos.

The structured interview is applied after having attended the client; response time was approximately 5 minutes long. The application of the instrument is carried out through a convenience sampling with a selection of 15 clients who agreed to answer a structured interview that collects information on the savings habit of the bank's clients, by which methods they do so, among other specifications; Fernández (2004, p. 154) comments that convenience sampling "consists in selecting the most convenient sample units for the study or in allowing the participation of the sample to be totally voluntary."

Once all interviews have been applied, the information is captured in the SPSS program for analysis and interpretation. The open questions answers that were generated spontaneously during the application of the instrument, supported the formulation of the conclusions and recommendations. 


\subsection{Instrument and Measurement of Variables}

The research instrument is made up of 15 questions, prior to its application, a pilot test was carried out with five users to apply corrections and adjustments to it.

The information is divided into two sections that investigate the following sections:

- Socio-demographic information of the interviewee: Section that is dedicated to describing their demographics and evaluating their socioeconomic status. It includes sex, age, income range, level of education, employment, and income level. Include the first 6 questions.

- Determinants of savings, are questions focused on knowing if the client saves or not and what motivates him to do so.

- Savings preferences, Investigates the tools that clients use for saving, if they do not, which ones they would like to save on and are known.

- Saving habits: Explores aspects related to the attitude that customers have for saving, for example, what they consider saving to be and if they don't save why they don't.

\subsection{Description of Variables}

- The sociodemographic characteristics considered in the study are gender, age, educational level, marital status, income and economic activity.

- The saving variable is defined according to Dornbusch and Fischer (2012) as "that part of income that is not consumed and postpones its use for a specific plan in the future",

- The financial habit variable is defined as a form of behavior acquired by the repetition of the same acts which help the personal economy since these behaviors

- Give direction, order and meaning to personal finances; some financial habits are having a budget, saving, investing, planning the use of money, and being in debt for a short time. This definition is a fusion of the definition of habit by Gómez (1997) and Red Financiera Credomatic (2008) with examples on financial habits.

- Savings instruments are the different formal and informal means that exist, such as savings accounts, tandas, or safe deposit boxes, among others (Own elaboration).

\section{RESUltS}

Regarding the habit of saving, the answers were divided since half correspond to men and the rest to women out of the seven interviewees who affirmed that they save. The savers had the following characteristics:

They are people whose age goes around 30 to 35 years old, most of them have bachelor's degree followed by postgraduate degrees, most of them are single, although married people also save, they are clients with employee occupation, with an income between $\$ 10,000$ to $\$ 30,000$ pesos and they save between $1 \%$ to $10 \%$.

On the other hand, the interviewees who do not save (eight cases) are mostly between 30 to 35 years old and 42 to 47 years old., their occupation are of employees and their level of studies is mostly bachelor's degree followed by interviewees with a high school level of studies. They have an average income between $\$ 15,000$ to $\$ 20,000$ pesos.

Due to the above described, it can be observed that half of the interviewees have the habit of saving and it is interesting that those who do not, receive high incomes and have a similar level of education to those who do save.

\subsection{Savings Instruments}

Regarding the way in which the interviewees save, four of them answered that they do so in a bank savings account, one person uses a tanda, another does it at home and one more answered the option "other" which corresponds to a saving Fund.

Of the interviewees who save in an account, half a month allocate $1 \%$ to $5 \%$ for this purpose, one saves between 6 and $10 \%$ and another saves between $11 \%$ and $20 \%$. The customer who saves in a tanda does so in a percentage between $1 \%$ and $5 \%$ and the one who saves at home does so in a percentage between $16 \%$ and $20 \%$.

As can be seen from seven people, four save in an instrument of the formal system (savings account) and three people prefer to use instruments of the informal savings system. 


\subsection{Saving Habits}

\section{Budget Use}

Regarding the habit of using a budget, the most popular answers were "almost always" and "sometimes", with five and two people respectively, use this tool. It is used by both men and women between 42 and 47 years of age, bachelor's degree level of studies and both married and single use it.

\section{Record of Expenses, Income and Debts}

The record of expenses, income and debts is similar to budget management, however, it is more specific since it is also important to keep a record of acquired debts, the savings that are going to be separated, the income received and the expenses to be covered. With this detail, clients can have better control over their personal finances and be able to plan their future. The answers were quite divided, two people answered that they "always" carry out the registration, another two answered "almost always" and "disagree" and one person totally disagreed.

Those who answered "always" carry out the monetary registration are men, between 36 and 41 years old, married, with a bachelor's level of studies, employees and with an income level between $\$ 10,000$ to $\$ 30,000$ pesos.

\section{Savings for Contingencies}

It is observed that four people answered that "sometimes" they save for contingencies, two "almost always" and one "disagreed". Those who "almost always" save are between 42 and 53 years old, half men and women, with a high school and bachelor's level of studies, employee occupation and income level between $\$ 10,000$ to $\$ 25,000$ pesos. Those who "sometimes" save for contingencies were also divided between men and women, the majority between 30 to 35 years old, married and single with the same percentage, with bachelor's and postgraduate level of studies and with incomes above \$ 20,000 and more than $\$ 30,000$. It is curious that those who have the discipline to save for contingencies have a lower income level than those who sometimes do, so it is not because it's not enough, but because they do not have the habit of doing so.

\section{Savings for Retirement}

Regarding the questioning of the Habit of saving for retirement or old age, two people dedicate part of their savings "almost always" to this heading, while another two "sometimes" and three people "disagree". Those who answered "almost always" save for old age correspond to male respondents, "sometimes" save, women and the majority were in disagreement, corresponding to men and women. Those who "almost always" save for this purpose are people between 42 to 47 years old, have bachelor's and postgraduate studies, are married, employees and independent professionals with incomes ranging between 10 to 15 thousand pesos and more than 30 thousand pesos. Those who do not save for this stage of their life are between 30 and 41 years old, surprisingly they have bacherlor's and postgraduate studies, they are employees, most of them single and with incomes between 20 to 30 thousand pesos.

\section{CONCLUSiOnS}

It is concluded that the financial habits of account holders who save are: managing a budget, controlling their income, debt, spending and saving, saving for contingencies and for old age, highlighting that clients who do not save if they did, would do so, through a bank savings account.

Torres (2015) states that in Mexico there is so little knowledge of financial savings, investment, insurance and credit products, coupled with the problems of millions of individuals without access to this sector. This is observed in the results of the interviews, since, out of fifteen people interviewed, 8 confirmed that they didn't save, and the main cause is because it is not enough their income to be saving, and in a smaller number, because they don't know how to do it.

Saving can be treated as formal or informal, since formal saving can be carried out in financial and banking institutions, on the other hand, informal saving is concentrated in personally assuming the safeguarding of capital or transferring it to a third party not legally certified to perform that task (Bohorquez, 2016). With the application of the interviews, the reasons why the interviewees did not save were determined, and it was determined that, six out of eight, commented that it was not enough and two that they don't know how to save. Additionally, it was identified that the interviewees who do 
not save, if given the opportunity, four would prefer it to be in a bank account, and the rest in some investment instrument and endowment, but none would choose to save in safe deposit boxes or save at home. Five out of eight interviewees agreed that to save it is necessary to save money, in the same way when saving, benefits are obtained in the future and that is why for achieving it, you have to manage to stop spending.

The habit of saving it is of geat importance in society since managing income should be something that all people know and master. It is crucial that the habit of saving is encouraged from an early age, so that economically active people will be aware of how they distribute their income, what they spend it on, how much they save and thus be able to achieve personal and family financial goals.

Being prepared in all stages of life is possible through the organization of savings, there are various instruments that help to this end and are formal and safe methods. Financial education can be learned and improved through knowledge and practice.

\section{REFERENCES}

[1] Ros, J. (2018). La economía mexicana: balance del 2017, principales tendencias, desafíos y problemas de la política económica. Revista de Economía Mexicana. Anuario UNAM (3). Recuperado de: http://www. economia.unam.mx/assets/pdfs/econmex/03/01Ros.pdf

[2] Zozaya, A. (2016). La crisis que viene en México Recuperado de: https://www.america economia.com /analisis-opinion/2018-la-crisis-que-viene-en-mexico

[3] Huidobro, A. (1995) La importancia del ahorro en la economía. Comisión Nacional de Seguros y Fianzas. Recuperadodehttp://www.cnsf.gob.mx/Difusion/OtrasPublicaciones/DOCUMENTOS\%20DE\%20TRAB

AJO\%20DESCRIPTIVOS/DdT62conimag\%20BV\%20ok.pdf

[4] Flores, M. (2013) ¿Cómo ahorramos los mexicanos?. Protege tu dinero. Pag 38

[5] Banco Mundial (2015). Inclusión financiera: Panorama general. Recuperado de: http://www.Ban comundial.org/ es/topic/financialinclusion/overview

[6] Forbes. (2016) 3 consejos clave de educación financiera. Revista Forbes Recuperado de: https://www. forbes. com. $\mathrm{mx} / 7$-consejos-de-educacion-financiera-para-mejorar-las-finanzas/

[7] CONDUSEF (2015) Finanzas personales a prueba de crisis. Recuperado de: http://www.condusef. gob.mx/Revista/index.php/usuario-inteligente/consejos/356-finanzas-personales-a-prueba-de-crisis

[8] Banco de Desarrollo de América Latina. (2013) La educación financiera en América Latina y el Caribe: Situación actual y perspectivas. $\mathrm{N}^{\circ}$ 12. Recuperado de: https://www.oecd.org/daf/fin/financialeducation/OECD_CAF_Financial_Education_Latin_AmericaES.pdf

[9] Torres, Y. (2015). Educación Financiera ausente en 90\% de las instituciones en México. El Financiero. Recuperado desde http://www.elfinanciero.com.mx/economia/educacion-financiera-ausente-en-90-de-lasinstituciones-en-mexico.html

[10] Lanzagorta, J. (2015) El ABC de las finanzas personales. El Economista. Recuperado de: http://eleconomista. com.mx/finanzas-personales/2015/01/26/abc-las-finanzas-personales

[11] Chu, M. (2017) Mis Finanzas Personales. Perú: Universidad Peruana de Ciencias aplicadas. Recuperado de:https://books.google.com.mx/books?id=IdKEDwAAQBAJ\&printsec=frontcover\&dq=que+son+finanza s+personales\&hl=es-419\&sa=X\&ved=0ahUKEwiGodDuytjmAhWwmOAKHXbUADg4ChDoAQhOMA $\mathrm{Y \# v}=$ onepage $\& \mathrm{q}=\mathrm{que} \% 20$ son $\% 20$ finanzas $\% 20$ personales $\& \mathrm{f}=$ false

[12] Delgado L (2009) Las finanzas personales. Revista EAN p.123

[13] Gómez, V. (1997) El pequeño Larousse Ilustrado. México: Ediciones Larousse.

[14] Dornbusch, R., Fischer, S. y Startz, R. (2016) Macroeconomía. México: Mc Graw Hill

[15] Aguilar A, y Valles Y. (2015) El ahorro en México: Evidencia en los hogares. Estudios económicos CNBV. Recuperado de: https://www.gob.mx/cms/uploads/attachment/file/71345/2015_Estudios_ economicos_CNBV_Volumen_3.pdf Recuperado el 5 de julio de 2019

[16] Red Financiera BAC Credomatic (2008) Libro Maestro de Educación Financiera, un Sistema para Vivir Mejor. Innova Technology. Recuperado de: https://www.credomatic.com/ guatemala/img/ img_sitios/ educacion_financiera.pdf

[17] Iregui-Bohórquez, A., Melo-Becerra, L., Ramírez-Giraldo, M. y Tribín-Uribe, A. (2018). Factores determinantes del ahorro formal e informal en Colombia, en Investigación Conjunta-Joint Research, 1, $101-131$

[18] Vázquez, A. (2015). Determinantes para participar en el mercado formal de productos financieros: El caso del ahorro y del crédito en México. Estudios Económicos CNBV. 3, 73-108. Recuperado de: https://www. gob. x/cms/uploads/attachment/file/71344/2015_Mercado_financiero_formal_e_informal.pdf 
[19] Villagomez, A (1993) El ahorro en México desde 1960: Estructura, evolución y determinación. México: CIDE.

[20] Comisión Nacional Bancaria y de Valores (2016). Sociedades Cooperativas de Ahorro y Préstamos (Socap) Recuperado en https://www.gob.mx/cnbv/acciones-y-programas/sociedades-cooperativas-deahorro-y-prestamo-socap

[21] Coru (2019). Qué es y cómo funciona una tanda de ahorro. Recuperado de: https://coru.com/blog/ finanzas/finanzas-personales/que-es-y-como-funciona-una-tanda-de-ahorro/

[22] BBVA (2015) Qué necesitas saber para alquilar una caja de seguridad en un banco. Recuperado de: https:// www.bbva.com/es/neobancos-que-son-y-como-operan/

[23] Blaxter, L., Hughes, C., y Tight, M. (2000). Cómo se hace una investigación, Barcelona España: Editorial Gedisa.

[24] Fernández, A. (2004) Investigación y técnicas de mercado. España: Esic Editorial.

\section{AUTHOR'S BIOGRAPHY}

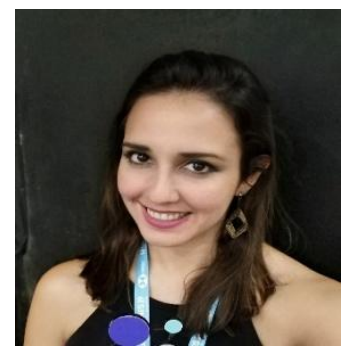

María Esther Mayagoitia Sánchez, is Master in Finance from the Autonomous University of Yucatán and degree in of Mérida, administration from the Higher Technological Institute Account Executive at Financial Institution in Mexico, being two consecutive years first national place in achievement of objectives (2018-2019) and also with national recognition on credit placement in 2017.

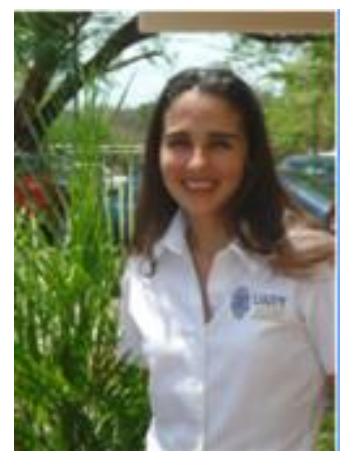

Laura Guillermina Duarte Cáceres, is Doctor of Administration, Professor at the Autonomous University of Yucatán, Coordinator of the Academic Team of Economics and Finance, certified by the National Association of Accounting and Administration Faculties and Schools (ANFECA), with PRODEP Recognition of the Secretary of Higher Education and Researcher on topics related to Personal Finance and Funding Sources.

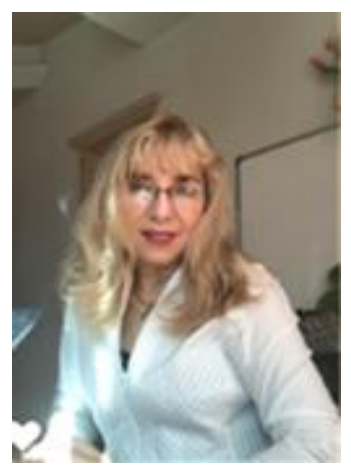

Yolanda Leonor Rosado Muñoz, is Doctor of Administration, full-time professor and coordinator of the Master's Degree in Finance program at the Autonomous University of Yucatán, certified by the National Association of Accounting and Administration Faculties and Schools (ANFECA), with PRODEP Recognition of the Secretary of Higher Education and Researcher on topics related to Personal Finance and Funding Sources.

Citation: M.F. María Esther Mayagoitia Sánchez, et.al. "Financial Habits of Savings by Customers of a Banking Entity" International Journal of Managerial Studies and Research (IJMSR), vol 9, no. 1, 2021, pp. 1-8. doi: https://doi.org/10.20431/2349-0349.0901001.

Copyright: () 2021 Authors. This is an open-access article distributed under the terms of the Creative Commons Attribution License, which permits unrestricted use, distribution, and reproduction in any medium, provided the original author and source are credited. 